\title{
Approaches to Establishing Communities Dedicated to the Promotion of Young Faculty's Scholarship of Teaching
}

\author{
Chun WANG \\ School of International Education, Henan University of Science \& Technology, Luoyang, \\ Henan, China
}

Keywords: Higher learning institution, Young faculty, Scholarship of teaching.

\begin{abstract}
With China's higher education entering into the new historical period of mass education, the introduction and practice of the ideas of scholarship of teaching contributes to the young faculty's growth and development. Approaches are discussed in this paper to establishing communities dedicated to the promotion of faculty's scholarship of teaching. Higher learning institutions should take initiative in the following aspects: establishing scholarship communities and faculty development center; sponsoring teaching activities rich in content and various informs; reforming the traditional faculty evaluation system to give full play to teachers' teaching creativity; creating teacher-student bonding relations, building teaching culture conducive to the harmonious interaction between faculty and students.
\end{abstract}

\section{Introduction}

After the entry of China's higher education into mass education, there is also a dramatic change in the make-up of the faculty in higher learning institution. The full-time teachers in common higher learning institution in China amounted to 1343100 in the year of 2010, of whom those under the age of 40 accounted for $63 \%$, and those under the age of 35 accounted for $47 \%$. While in the year 2012, there were 1440300 full-time teachers in China's higher learning institutions, more than $74.7 \%$ faculty were under the age of 45 . The young faculty has made up the majority of the group, it naturally follows that they will play a key role in the sustainable development of colleges and universities and competitiveness of China's higher education in the world.

\section{Teaching Crisis in Higher Learning Institutions Calls for Promoting Young Faculty's Teaching Ability}

Teaching is the widely recognized basic function with which colleges and universities are originally equipped. In recent years, the impact of negative factors concerned on higher education has been so strong that there is less stress than ever laid on teaching and teaching is faced with the danger of being ignored. Under the push from all walks of life, academic research is the favor of education system at all levels, then university ranking, teacher performance appraisal, salary and reward are based on the research results evaluation. The importance of academic research is been soaring, an explicit example is that the current teacher evaluation system focuses on the quantity of published articles, the ranking and amount of funding, the number of the postgraduate training, etc. Even there is an intersection between teaching and academic research, the notion of "academic research nourishing teaching" is currently popular. Colleges and universities spare no effort to pursue the "excellence without soul", then faculty has no loyalty to work, not being committed to students and effective 
teaching. The faculty's emphasizing research but neglecting teaching has currently been widespread in Chinese higher learning institutions, especially in the research-oriented universities. Teaching in colleges and universities are in danger of being marginalized, even excluded.

Quality is the lifeline of the development of higher education. Presently, there are five striking phenomenon existing in the current young faculty development, namely " more introduction, less cultivation", "more degree, less ability", "more form, less content", "more research, less teaching", "more quantity, less quality" [1]. Teaching is the top priority for the higher learning institutions, and promoting young faculty's teaching ability is the fundamental guarantee of quality higher education.

\section{The Use of Scholarship of Teaching for Reference to Young Faculty Development}

In 1990 contemporary American famous educator Ernest L. Boyer published a report Scholarship Reconsideration: The Priorities of The Professoriate. It is advanced in the report that academy should include four different and interrelated aspects: the scholarship of discovery, the scholarship of integration, the scholarship of application and the scholarship of teaching. The report redefines a new academic paradigm, giving academic thoughts and new connotation of the teaching, therefore having a positive influence on the higher education around the world.

As one type of scholarship, teaching has all characters common to academy. International experience shows that the equilibrium relationship between teaching and academic research, there are still great challenges facing scholarship of teaching in such aspects as cultural recognition and rules formulation [2]. Considering the complexity of the structure, the diversity of school positioning, and difference in the following aspects ---teaching resources, quality of students, social demands, the school authorities should take initiative to establish the communities dedicated to the promotion of young faculty's scholarship of teaching.

\section{Universally Establishing of Institutions for Faculty Development, Improving Young Faculty's Scholarship of Teaching in a Well-rounded Way}

Presently institutions named teacher development center, teaching research center, or teaching support center are set up at colleges. Aimed to promote young faculty's professional level and teaching ability, these institutions can take the following measures to animate the related activities rich in contents, various in forms.

Great importance should be consistently attached to the collective teaching activities organized by school, department, teaching and research office. As the organizations at the grass-roots level are discipline/specialty-oriented, it is necessary to retain such traditional methods as teaching and research, collective lesson preparation, etc. Such collective teaching and researching activities favor building a relatively close teaching academic community, guarantee the quality of teaching, practicably promote the refinement on teaching on the whole.

Establishing the long-term mechanism enhances young faculty's scholarship of teaching. Now science and technology are advancing in width and depth at the unexpected rate, colleges have the multi-disciplinary advantage and can provide platform to communicate, then it is also essential to organize a teaching salon composed of teachers of various interdisciplinary fields. Through teaching seminars, experience exchange, young faculty share successful experience and advanced teaching ideas. Through the research-oriented teaching 
demonstration class and the leading teachers' diagnosis of teaching problems, teaching resources inside and outside the college are exploited to prompt a variety of brainstorming.

Sponsoring teaching and research projects of different levels and types creates unity of teaching and research. There is the fact that teaching stimulates academy and academy feeds academy, the integration of both is a solution to the problem of conflicts caused by faculty's pursuit of teaching and academy, therefore benefiting the healthy development of both teaching and personal academic career [3].

\section{Reforming the Traditional Faculty Evaluation System, Giving Full Play to the Young Faculty's Teaching Creativity}

Reforming education evaluation model refers to the change in faculty evaluation system from the "past-orientation" to the "future-orientation", to stimulate the potential of human resources and promoting teachers' comprehensive development. To carry out developmental evaluation, the traditional appraisal system based on reward and punishment needs to be converted into a system based on teacher development evaluation. By developmental performance evaluation, colleges and universities attach great importance to the mutual communication, make full analysis of the strengths and weaknesses of employees, find out the gap existing between teachers' ability and professional development, and factors influencing teachers' performance improvement. Based on the above-mentioned, faculty's training and cultivating plan are formulated accordingly, providing help and guidance for the ascension of their future performance, promoting the teachers' continuous improvement and development. Developmental evaluation should be implemented as a mainly evaluation style applicable to the young faculty in the important period of professional development.

To give full play to teachers' teaching creativity, young faculty should be given freedom to arrange the proportion of research and teaching work on their own initiative. Young faculty should be blessed with bigger flexibility, deciding on the engagement in research or teaching in the future period based on their own personal plans of career development. This choice space can make them more focus on selected areas, satisfying the needs of young faculty at different ages, and of their different career pursuits. This sense of autonomy will inspire young faculty to devote themselves to promoting their work, whether it is a theoretical breakthrough in the teaching method or in practical innovation.

To improve the faculty evaluation system, teaching incentive mechanism is formulated. There should be specifications concerning teaching scholarship, and the increase of teaching scholarship evaluation weight in the process of teachers' title promotion review. Through the incentive mechanism, a comprehensive evaluation includes their teaching research, teaching performance, teaching devotion, teaching effectiveness, then young faculty have inner motive power to inspire their self development and self-improvement.

\section{Creating the New Relationship between Faculty and Students, Building the Teaching Culture of Harmonious Interaction}

The pursuit of "excellence in teaching and learning" has always been the deep root of a university distinct from the special research institutions. The emergency of outstanding teachers and students in a constant stream is the characteristics of the colleges and universities. China is making efforts to build a higher education system of reasonable structure, accurate positioning and clear division, to defend the elite education, perfect mass education, and develop universal 
education [4]. Colleges should pursue in the areas relevant to their own school-running orientation to train professional elite talents.

Measures are taken in management innovation to create a new relationship between faculty and students. Adhering to the concept of "people-oriented", the school authorities should rely on scientific teaching management to mobilize enthusiasm about teaching in both sides of faculty and college students, giving faculty teaching autonomy, students learning freedom, protecting the rights of teachers to teach and students to choose [5]. The ecology of a normal university is made up of the teaching masters and prominent students, their interaction with each other constitutes a virtuous teaching culture of a harmonious relations, sustainable perfection.

The atmosphere of respect for faculty should be built in all aspects. Schools should consolidate and upgrade the ethics culture of professional teachers, whose core is commitment to teaching, refinement on performance, affection for students, example setting, then building the strong atmosphere of educating people first in the school. Enriching teaching credit system and recognizing the faculty of excellent teaching will bring the teachers a sense of accomplishment in the teaching work. A rich atmosphere of respect for teachers and emphasis on teaching will motivate young faculty's enthusiasm, initiative and creativity, so as to guarantee improvement on teaching quality.

\section{Conclusion}

China's higher education, having achieved the denotative growth in students' scale, presently needs strengthening connotative development and focusing quality of talent training. The introduction of "scholarship of teaching" and establishment of the corresponding institution are conducive to the accomplishment of the project of young faculty's improvement on teaching ability. The intrinsic mechanism characteristic of organizational institutions, regular activities, incentive evaluation, and interaction between parties related to teaching as well will absolutely promote both the faculty development and talent training in higher learning institutions.

\section{Acknowledgement}

This research was financially supported by Henan Province Education Department humanities and social science research key project (2013 -ZD -114), Henan Province philosophy and social sciences planning project (2015 BYY030).

\section{References}

[1] X. J. Fan. Systematically constructing cultivation mechanism of young faculty's teaching ability, http://news.gmw.cn/2014-12/02/content_14028140.htm

[2] Y.L. Hao. Progress and challenges of international teaching academy movement- based on the analysis of Britain, America and Australia, Modern University Education, 3(2014): 44-49

[3] Y. Yuan. Dealing with changes in education context to improve the young faculty's teaching quality, China's higher education, 3/4(2014): 54-56

[4] Z. Zh. Liu. The background and ideas of the transformation and development of local undergraduate colleges and universities, China's higher education, 20 (2014): 50-53 
[5] J. Ch. Mei. Return to education: the only way for university education reform, China University Teaching, 7(2014): 45-47 